\title{
My Year as an AMS Congressional Fellow
}

\section{Anthony J. Macula}

Each year, the American Mathematical Society (AMS), in conjunction with the American Association for the Advancement of Science (AAAS), sponsors a Congressional Fellow who spends the year working on the staff of a Member of Congress or a congressional committee, as a special legislative assistant in areas requiring scientific and technical input. The program includes an orientation on congressional and executive branch operations and a year-long seminar series on issues involving science, technology, and public policy. For information about applying for the Fellowship, visit the page bit. $7 y /$ AMSCongressiona1Fe11owship. The deadline for applications for the 2017-2018 Fellowship is February 15, 2017.

During the 2015-2016 academic year, I had the honor of serving in the position of AMS Congressional Fellow, as one of 284 AAAS Science and Technology Policy Fellows. It was fun and exciting to engage with them on a broad range of topics in science policy, advocacy, and diplomacy, in both the natural and social sciences, and then to think about how my mathematical training could be applied. I ultimately took a somewhat mathematical approach in drafting legislation in health, trade, and cybersecurity.

The Fellowship starts with a two-week "You are in Washington, DC" orientation that included many exciting, informative sessions (as well as some annoying though probably necessary ones). Where else could one ask President Obama's chief science advisor about the President's feeling on a science issue, or the former presiding judge of the Foreign Intelligence Surveillance Act (FISA) Court what sort of technical advice and expertise the FISA Court has at its disposal when deciding the legality of federal surveillance programs? Another highlight was the daylong "How Congress Works/Doesn't Work" session by the Congressional Research Service, a nonpartisan division of the Library of Congress, which turned out to be a great resource for me during my Fellowship.

Executive Branch Fellows know their federal agency office placements before they arrive in DC, but Congressional Fellows do not. To assign Fellows to Congressional offices, the AAAS employs a process similar to match. com. Congressional Fellows submit their profiles, and Congressional offices submit their staffing needs. After

Anthony J. Macula is professor of mathematics at SUNY Geneseo. His e-mail address is macula@geneseo.edu.

For permission to reprint this article, please contact: reprint-permission@ams . org.

DOI: http://dx.doi.org/10.1090/noti1466 orientation, the AAAS circulates these documents, and the placement process begins with a "coming out" mixer, where the two sides meet. Senators and Members of Congress come to talk up their offices and their past experiences with Fellows, while their aides mingle, looking for the Fellows they feel will be a good match. After days of e-mails and interviews, everyone is placed. I chose the office of Congressman Jim McDermott because I felt that he valued my professional and scientific background. I was grateful to have a personal interview with the Congressman. This isn't so unusual, but many other Fellows are interviewed only by staff.

Congressional offices employ Fellows in various ways, and the position of a Fellow in the office's chain of command can vary from office to office. Congressman McDermott was quite accessible to all his staff, including Fellows. He felt that his office could learn from a Fellow just as a Fellow could learn from his office, and together we discussed many issues. I was asked to think about higher education and trade issues that are brought before the powerful House Ways and Means Committee of which Congressman McDermott is a member. One of my tasks was to prepare opinion papers for the Congressman to consider. I was also allowed to work on some of my own relevant interests, and I chose cybersecurity.

Orientation impressed upon us that getting the three Ps-Policy, Procedure, and Politics-right was the way to reach legislative nirvana. That is a tall order. Our chief of staff encouraged me to press on, saying, "House Speaker Paul Ryan can't even get the three Ps to jibe within his own House majority caucus." The title of my year-end presentation was, "Policy, Procedure, and Politics: $2+\epsilon$ Outta Three Ain't Bad."

I tried to extend the boundaries of existing law by proposing scope-broadening amendments. I explained this approach to the office by comparisons to complex 
numbers and non-Euclidean geometry, and I felt that they got a little insight into how a mathematician thinks.

I provided an argument in support of Senator Sanders' College For All Act; Congressman McDermott became the first co-sponsor of that bill. In addition, I drafted two bills that Congressman McDermott introduced: "The Cybersecurity Systems and Risks Reporting Act" and "Protecting America's Health Measures Act." The first amends the Sarbanes-Oxley Act of 2002 to protect the public by expanding the requirements on public company boards, management, and public accounting firms to include cybersecurity systems and risks. It also stipulates that a publicly traded company must appoint a cybersecurity specialist to its audit committee. The second was introduced to improve free trade agreements. The Trans-Pacific Partnership (TPP) has a provision that protects anti-smoking measures from investor-state dispute settlement arbitration. Our goal was to extend this provision to apply to all US health measures. This extension was a tricky thing to propose, because the TPP can't be directly amended. However, its implementing mechanism can be, and this is what our bill does. It makes explicit that protecting America's health measures from corporate trade lawsuits is an important trade negotiating objective of the United States.

It is interesting to note that while the second bill has six House cosponsors and the first has none, our chief of staff felt that the first was more politically successful because it received positive interest from some professional organizations such as the American Institute of CPAs and it was cited by some news organizations such as Bloomberg.

I am very grateful to the AMS for funding the Fellowship and to the AAAS for the program support. It was an enriching experience, and I feel that I am a better citizen scientist, with a deeper understanding of policy and advocacy, because of it.

Editors' Note: The AMS Congressional Fellow for 2013-2014 was Karen Saxe, who was recently appointed as director of the AMS Washington Office. Saxe wrote an article about her Fellowship experiences that appeared in the January 2015 issue of the Notices. The December 2016 issue of the Notices carried an interview with Saxe upon her appointment as the new Director of the AMS Washington, DC, office; the interview was conducted by Notices Associate Editor Harriet Pollatsek.

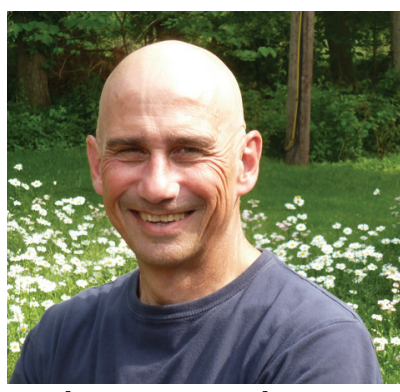

THE AUTHOR
American Mathematical Society

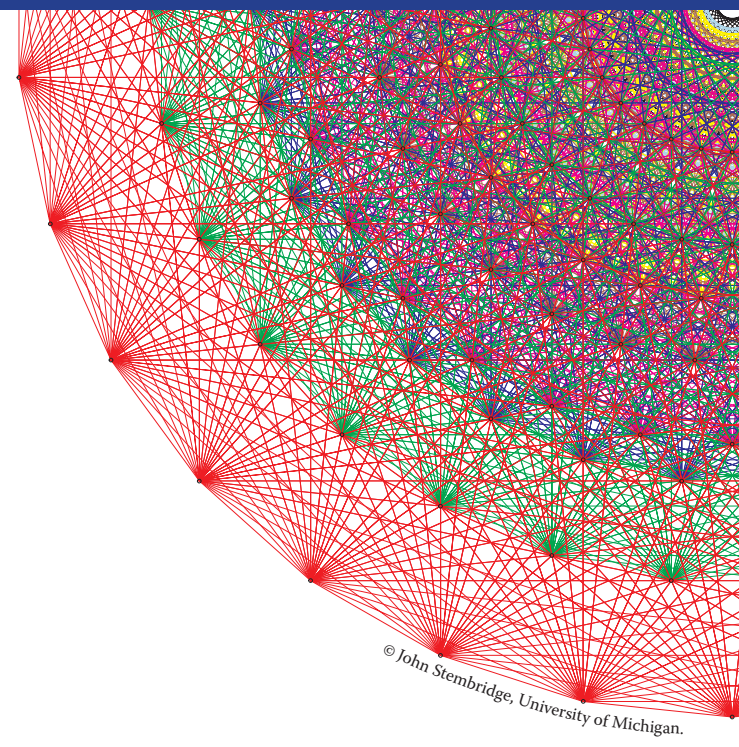

AMERICAN MATHEMATICAL SOCIETY MathSciNet Mathematical Reviews

www.ams.org/mathscinet

\section{MathSciNet is the most complete and reliable source for your research}

MathSciNet contains information on over 3 million articles and books, with direct links to almost 2 million articles in over 1,800 journals. MathSciNet includes expert reviews, personalizable author profiles, and citation information on articles, books, journals, and authors. Use it to:

- Quickly get up to speed on a new topic

- Look up a researcher's body of work (and find his/her Erdős number!)

- Find an article or book and track its reference list

- Research a math department to prepare for a job interview

- Personalize your author profile

\section{Howto-Subscribe/Purchase}

Go to www.ams.org/mathsciprice to learn more about MathSciNet, including information about joining a consortium, subscription rates, and a 30-day free trial. 